\title{
The Implementation of Various Games to Develop Children Intelligence in Indonesia
}

\author{
Khusnul Laely ${ }^{1}$, Debby Ayu Nandiya ${ }^{2}$, Lili Permatasari ${ }^{3}$ \\ \{khusnullaely86@ummgl.ac.id $\left.{ }^{1}\right\}$ \\ Pendidikan Guru- Pendidikan Anak Usia Dini, University Muhammadiyah Magelang, Indonesia ${ }^{1,2,3}$
}

\begin{abstract}
The purpose of this research is to find out the implementation of the arrangement of various main in developing children's intelligence. The research method used in this research is survey method. This study used questionnaires, interviews and observation sheets as a means of collecting research data conducted at 21 PAUD institutions in Kebumen, Purworejo, Wonosobo, and Temanggung districts. Data analysis using descriptive quantitative. The results showed that $57.2 \%$ of PAUD unit institutions have made arrangements for various games, $33.3 \%$ have not made arrangements for various games, and $9.5 \%$ of PAUD institutions have not organized safety activities. The various games was prepared by the class teacher with $14.3 \%$ as many as three variation and $85.7 \%$ of the institution prepared four variation in one day. The arrangement of various games was carried out in the morning before the learning activities were carried out with $61.9 \%$ of teachers coming 30 minutes before the learning activities. Based on the results of the research, it can be concluded that learning activities will get the results of maximum intelligence development if the teacher gives the freedom to play to children, namely by planning and structuring various games before the learning activities are carried out so as to raise children's curiosity, as well as give freedom to children to choose the various games in accordance with the interests of children.
\end{abstract}

Keywords: Arrangement of games, Children's intelligence, Early childhood

\section{Introduction}

Early childhood is an individual aged 0-8 years where at that age the child is undergoing a very rapid development in the human life span [1]. This age is often referred to as the golden age. Montessori argues that at this time it is also called sensitive periods, which are periods where children easily record and receive the stimulus obtained from the environment both by educators, parents and the child's surroundings [2]. This period will not be repeated in the future and occurs only once during human life. The position of play for a child is life and life is play which means the child learns through play [3]. Therefore, all learning activities presented for children are packed with play activities involving all senses owned by the child. Catron and Allen argue that the main purpose of children's play activities is so that all aspects of children's development can develop optimally and the occurrence of interactive communication [4]. In connection with that, an institution should have a curriculum that aims to develop all children's potential so as to create a fun learning atmosphere for children. The curriculum is compiled and developed by a unit of PAUD institutions to develop the knowledge, creativity, skills, and attitudes that children have as a provision to live the next life [5]. Getz has conducted research on the test methods used to measure the number, complexity, and setting of play resources in 
preschool classes, the results of which showed the number of conflicts that occurred or an increase in significant conflicts with the various games provided [6]. Robert conducted research on the provision of early interventions while playing for shy children. Research conducted by conducting the act of providing special training for shy children by approaching in emotional regulation strategies and relaxation techniques for handling shy children in developing their intelligence [7]. In connection with that, Bratton revealed that play therapy is a responsive means that can express the child's experiences, thoughts, feelings, and intelligence [8].

Intelligence is the ability that children have in solving problems experienced by children as well as the ability to create a certain work in the child's life [9]. Intelligence has been possessed by the child since birth and can be developed until adulthood. Children's intelligence should be developed as early as possible by stimulating the five senses possessed by the child. Intelligence is one of the capitals that can be utilized while learning. According to Gardner, the intelligence possessed by the child can be seen from the extent to which in solving problems, generating new problems to solve, and the ability of the child to create things [5]. Gardner's research results that human have eight intelligences and use them in an individualized way that is in accordance with the abilities of each child, each child is able to develop according to their intelligence, and each intelligence works together to grow aspects of its development [10]. The nine children's intelligences included linguistic intelligence, musical intelligence, mathematical logic intelligence, physical and kinesthetic intelligence, intrapersonal intelligence, interpersonal intelligence, spatial intelligence, naturalist intelligence, and spiritual intelligence [3].

In fact, learning that supports the achievement of the potential of each child is centered on children (student center). Student center approach is a learning activity that encourages interaction between teachers and children and interaction between children and other friends that can lead children to become critical thinkers, able to make choices, imaginative and creative and innovative in their lives [11]. This is in line with fisher's research in which the results of her research on play showed that low physical activity in early childhood results in poorer working memory in adulthood [12]. Teachers plan every learning activity carried out in the form of a Learning Implementation Plan. But what goes unnoticed is the various games that has been planned in the Draft Implementation of Learning not all institutions do the arrangement of various games and provide opportunities for children to choose a various game according to the interests of children. Therefore, in this study raised the issue of the implementation of the arrangement of various games in developing children's intelligence.

\section{Method}

This research uses survey method using quantitative approach. The research aims to find out the conditions and phenomena in the field. Data obtained through questionnaires, interviews, and direct observation of learning activities. Research data are analyzed using descriptive quantitative analysis. The analysis is illustrated by the calculation of numbers. The results of the analysis will be described descriptively. In this study, researchers will describe and analyze about the implementation of the arrangement of various games in developing children's intelligence.

This research was conducted in 21 early childhood education institutions both Daycare, Play Group, Raudhatul Athfal, Bustanul Athfal, and kindergartens in Temanggung, Purworejo, Wonosobo, and Kebumen districts. The research procedure begins with (a) The preparation of questionnaires, interview guidelines and observation sheets for direct observation guidance on 
learning activities; (b) Researchers conduct interviews with principals and teachers to find out the extent of implementation of the arrangement of various play and abilities owned by the child; (c) Researchers observe the implementation of the arrangement of various main in developing children's intelligence in learning activities; (d) Based on the results of interview answers, and the results of observations directly in the process of learning activities, researchers identified the implementation of various play arrangements in developing children's intelligence.

\section{Results and Discussion}

\subsection{Result}

\subsubsection{Implementation of various games arrangement in learning activities}

In fact, every unit of early childhood education institution has a curriculum that serves as the basis for planning learning activities. The curriculum is designed to maximize learning interactions in order to achieve the expected learning goals [13]. The curriculum includes all the indicators that must be taught to the child and how to teach them by making plans that will be carried out during one semester, one week, and one day [14]. The planning of learning activities that are arranged contains all aspects of children's development including aspects of language, cognitive, emotional social, language, moral religion, and art with a variation of planned activities.

One variation of games prepared can develop up to two, three, four, even five aspects of child development. Based on the results of the research obtained the use of tools and materials derived from the surrounding area including various fruits (blimbing, grapes, apples, bananas, salak, dragon fruit, melons, strawberry, star fruit, etc.), trees (banana trees, salak trees, etc.), used materials (milk boxes, used bottles, and packaging), clay, banana fronds, planting medicines (kencur, ginger, galangal, etc.). After the researchers conducted the study, it was found that not all institutions make arrangements for variation of game before learning activities begin. Obtained institutions that do the arrangement of variation of game before children come into the classroom, institutions that do not do the arrangement of various games where the arrangement is carried out when the core activities, and also there are still institutions that have not done the arrangement of security activities. The data of variation of game arrangement can be seen in Table 1.

Table 1. Implementation of various games arrangement in learning activities

\begin{tabular}{clcc}
\hline No & Indicator & $\mathrm{N}$ & Findings (\%) \\
\hline 1 & PAUD unit institutions have made arrangements for various games & 12 & 57,2 \\
2 & PAUD unit institutions have not made arrangements for various games & 7 & 33,3 \\
3 & PAUD unit institutions have not made arrangements for safety activities & 2 & 9,5 \\
\hline & & 21 & 100 \\
\hline
\end{tabular}

Based on the Table 1, not all units of institutions do the arrangement of various games. This is evident from the research results of $57,2 \%$ of the institutions that have organized the various games. Thus, it is necessary to approach the PAUD unit to organize the various games. Learning activities that provide a various game and make interesting arrangements and allow children to choose games according to children's interests show that the institution unit has implemented 
learning activities according to the interests of children. This is in line with Miller where the preparation of the curriculum as a form of children's play activities program should prioritize the freedom to be creative and explore and the role of adults only as facilitators [15].

\subsection{2 various games offered in learning activities}

The unit of early childhood education institutions has a curriculum that is implemented in learning activities. The curriculum owned by the institution as the basis for carrying out learning activities. The various games are prepared by the institutions both made arrangements before learning activities that can provide a motivational impact on learning for children as well as a various game that is organized when core activities are carried out. In fact, the success of learning activities depends on the learning planning that has been prepared and developed by the educators of their respective institutions. Based on the results of the study found paud institutions that in one day prepare 4 and 3 variations of games. This can be observed in the following table 2 .

Table 2. Various games in day learning activities

\begin{tabular}{cccc}
\hline No & Indicator & $\mathrm{N}$ & Findings (\%) \\
\hline 1 & PAUD unit institutions plan 3 various games & 3 & 14,3 \\
2 & PAUD unit institutions plan 4 various games & 18 & 85,7 \\
& & 21 & 100 \\
\hline
\end{tabular}

Based on the Table 2, PAUD unit data found that plan 4 various games in one day as much as $85.7 \%$ and who prepare 3 variations of amen as much as $14.3 \%$. This can be interpreted that $85.7 \%$ of PAUD institutions have facilitated the freedom of learning for early childhood by preparing play options according to children's interests.

\subsubsection{Teacher discipline is seen from the arrival time in learning activities}

Various games that have been planned in one day by educators in order to implement the curriculum that has been compiled and developed, preferably before the learning activities begin at least 30 minutes the teacher has come first to prepare and organize the various games that has been planned. Well-planned learning activities will play a role in supporting the expected achievement of learning activities. After the researchers conducted observations and interviews to 21 PAUD institutions, then the results of teacher discipline data when coming to school to come early and prepare the various games that has been planned in the curriculum can be observed in table 3 .

Table 3. Teacher discipline as seen from arrival time

\begin{tabular}{cccc}
\hline No & \multicolumn{1}{c}{ Indicator } & $\mathrm{N}$ & Findings $(\%)$ \\
\hline 1 & 5 minutes before the learning activity & 1 & 4,8 \\
2 & 10 minutes before the learning activity & 2 & 9,5 \\
3 & 15 minutes before the learning activity & 1 & 4,8 \\
4 & 20 minutes before the learning activity & 2 & 9,5 \\
5 & 25 minutes before the learning activity & 1 & 4,8 \\
6 & 30 minutes before the learning activity & 13 & 61,9 \\
7 & 45 minutes before the learning activity & 1 & 4,8 \\
& & 21 & 100 \\
\hline
\end{tabular}


Based on the data findings above, it can be found that $61.9 \%$ of teachers come to school 30 minutes before the learning activities, and there are still $33.4 \%$ of teachers who come to school less than 30 minutes before the learning activities. This is one of the factors that causes teachers not to organize various games before learning activities.

\subsection{Discussion}

Based on the findings of the study that showed the findings that $85.7 \%$ of paud institution units have prepared 4 variations of play in one day. However, from $85.7 \%$ it is not all done environmental arrangements. The unit of institutions that organized the various games only reached $57.2 \%$. One of the factors that influence the unit of the institution does not make arrangements for the various games is because there are still $33.4 \%$ of teachers coming to school in less than 30 minutes. Thus, the discipline of teachers in structuring will affect the success of learning activities. The number of play variations planned in learning activities is directly proportional to the growing intelligence. The more various games planned in one day, the more interactions that occur in the learning process on that day so that the more intelligence owned by children includes linguistic intelligence, musical intelligence, mathematical logic intelligence, physical and kinesthetic intelligence, intrapersonal intelligence, interpersonal intelligence, spatial intelligence, naturalist intelligence, and spiritual intelligence [3]. This is in accordance with Getz's research which states that the more various games activities, the more interactions that occur in learning activities [6]. Learning activities are carried out by planning activities that provide freedom to explore and creativity [15] in accordance with the development of children, namely by giving freedom to children to play by choosing their own various games that children are interested in and supporting the freedom of learning program.

\section{Conclusion}

Based on the results and discussions he had above, it can be concluded that learning activities will get the results of maximum intelligence development if the teacher gives the freedom to play to children, namely by planning and structuring a various game before the learning activities are carried out to raise children's curiosity, as well as give freedom to children to choose the various game according to the interests of the child. The next advice for researchers is to conduct research on what kind of play can develop each child's intelligence.

\section{Acknowledgement}

The speech of love was conveyed to the Early Childhood Education Teacher Education Study Program that has funded this research, so that the research can run smoothly and get results that can contribute to Early Childhood Education. 


\section{References}

[1] Berk, Scaffolding Children Learning: Vygotsky and Early Childhood Education. Washington: DC: NAEYC, 1995.

[2] E. G. Hainstock, Metode Pengajaran Montessori untuk Anak Prasekolah. Jakarta: Pustaka Delapratasa, 1999.

[3] Y. N. Sujiono, Konsep Dasar Pendidikan Anak usia Dini, Keempat. Jakarta: PT Indeks, 2011.

[4] C. . dan J. A. Catron, Early Childhood Curriculum: A Creative Play Model, 2 nd Edition. NewJersey: Merill Publ., 1999.

[5] B. S. Sujiono, Yuliani Nurani, Bermain Kreatif Berbasis Kecerdasan Jamak. Jakarta: PT Indeks, 2010.

[6] S. K. Getz, "A Test of a Method f or Quantifying Amount, Complexity, and Arrangement of Play Resources in the Preschool Classroom *," J. Appl. Dev. Psychol., vol. 3, no. 4, pp. 295-305, 1982.

[7] R. J. Coplan, Chapter 8: Play skills for shy preschoolers: A social skills training and facilitated play (SST-FP) early intervention program. Academic Press, 2020.

[8] S. C. Bratton, E. C. Dafoe, and N. Texas, "Play Therapy," Encycl. Ment. Heal. (Second Ed., vol. 3, no. 1942, pp. 278-283, 2016.

[9] H. Gardner, Multiple Intelligences: The Theory in Practice A READER. USA, 1993.

[10] B. C. dan D. D. Campbell, Linda, Teaching and Learning through Multiple Intelligences. Depok: Inisiasi Press, 2002.

[11] P. A. dkk Coughlin, Menciptakan Kelas yang Berpusat pada Anak. Washington, D C: Children's Resources International, 2000.

[12] P. G. Fisher, "Remember to play and play to remember," J. Pediatr., vol. 188, no. September, p. 1, 2017.

[13] M. K. dan D. F. K. Kitano, Gifted Education A: Comprehensive View. Boston: Little, Brown and Company, 1986.

[14] K. Pendidikan and D. A. N. Kebudayaan, "Kemendikbud RI Tahun 2015 tentang Rencana Strategis Kementrian Pendidikan Dan Kebudayaan 2015 - 2019,” vol. 51, no. 2, pp. 1-205.

[15] K. dan L. G. M. Albrecht, The Comprehensif Infant Curriculum. Beltville MD: Gryphon House., 2000. 